\title{
Lovage Oil
}

National Cancer Institute

\section{Source}

National Cancer Institute. Lovage Oil. NCI Thesaurus. Code C107325.

The essential oil of Levisticum officinale or the oil extracted from its roots. The leaf oil is used for the treatment of digestive ailments and in skincare. 